\title{
Significance of detection of extra metacentric microchromosome in amniotic cell culture
}

\author{
RENÉE BERNSTEIN, C. HAKIM, B. HARDWICK, AND G. T. NURSE \\ From the Department of Human Genetics, School of Pathology, The South African Institute for Medical \\ Research and University of the Witwatersrand, Johannesburg, South Africa
}

SUMMARY A metacentric bisatellited microchromosome was detected in all metaphases from an⿳亠口冋口𧘇 amniotic culture performed because of maternal age. A wide-ranging survey of the literature failed to ${ }_{\mathrm{Gr}}$ disclose any consistent anomaly associated with such a marker, but did reveal that the clinical pictureiv of patients manifesting it could range from complete normality through mental retardation to $a_{\omega}$ variety of deformities. The parents elected for termination, and the only deformity detected in the $e_{\circ}^{\infty}$ abortus was fixed talipes equinovarus. The implications of the finding of this marker chromosome on? amniocentesis, believed to be reported for the first time here, are discussed particularly in the context $\vec{\nabla}$ of genetic counselling.

Numerous accounts of the finding of an extra metacentic microchromosome have appeared since the anomaly was first reported by Ilberry et al. (1961). In some of these reports the microchromosome has been found incidentally in a phenotypically normal person during surveys, or as a family trait; in others, it has been associated with congenital abnormalities.

We wish to report what we believe to be the first detection of such a marker in an amniotic cell culture, and to discuss the prenatal implications of this finding in the context of genetic counselling.

\section{Case report}

A 40-year-old Caucasoid woman was referred rather late (at the 18th week of pregnancy) for amniocentesis on account of advanced maternal age. She had produced 2 normal liveborn sons, now aged 8 and 5 years, and had aborted spontaneously three times, always during the first trimester. She is Rh-negative, and her husband Rh-positive; the first abortion took place after the birth of her first son, when she did not receive anti-D serum, and the second and third after the birth of her second son, who is Rh-negative. No investigations had been carried out on either abortus. There was no paternal or maternal family history of inherited disease, and the present pregnancy was proceeding normally. Questioning about drug ingestion, infection, or exposure to radiation elicited nothing of relevance. Transabdominal amniocenReceived for publication 24 January 1977 tesis was performed after prior ultrasonic localisation of the placenta; a sample of clear fluid was obtained, and cells from it were cultured for karyotyping. Routine $\alpha$-feto-protein estimation of amniotic fluido showed normal levels for the period of gestation $(<16 \mu \mathrm{g} / \mathrm{ml})$.

\section{CYTOGENETIC FINDINGS}

Analysis of 45 Giemsa-stained amniotic fibroblas metaphases disclosed the karyotype 47,XY+mar: (Fig. 1). There was random technical loss of chromosomes from 9 cells, but the extra chromosome was present in all of them. It was small and metacentric, and without obvious satellites in unbanded meta phases, though in 10 of the 45 cells association with acrocentric chromosomes was obvious. The regular chromosome complement showed a normal banding pattern on trypsin-Giemsa and quinacrine mustard treatment. Giemsa banding did not assist in identifying the nature of the micro-marker (Fig. 2). The marker chromosome fluoresced clearly in all meta phases and in some cells it had a distinctly bisatellited appearance (Fig. 3a).

Karyotyping of both parents and both childrenk disclosed no evidence of any chromosomal anomaly and screening of 100 cells failed to detect any sign of . mosaicism for the marker in either parent. The mother had prominent satellites of one chromosome 21 and one 22 (Fig. 3c), and one paternal chromosomet 22 had very elongated stalks terminating in promi $\frac{\rho}{?}$ nent satellites (Fig. 3b). The latter had been inherited 2 


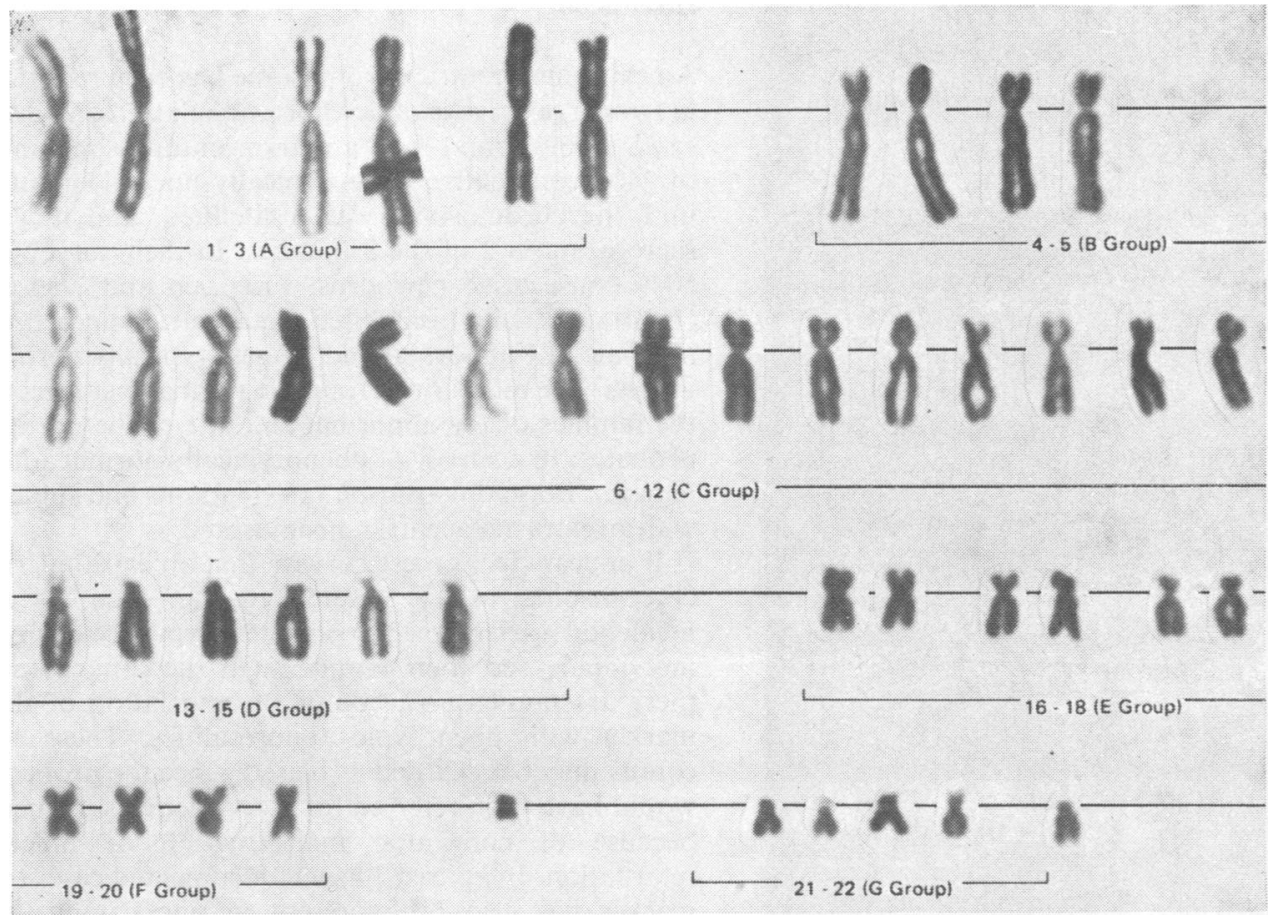

Fig. 1 Unbanded karyotype of amniotic cells showing the presence of the extra metacentric microchromosome.

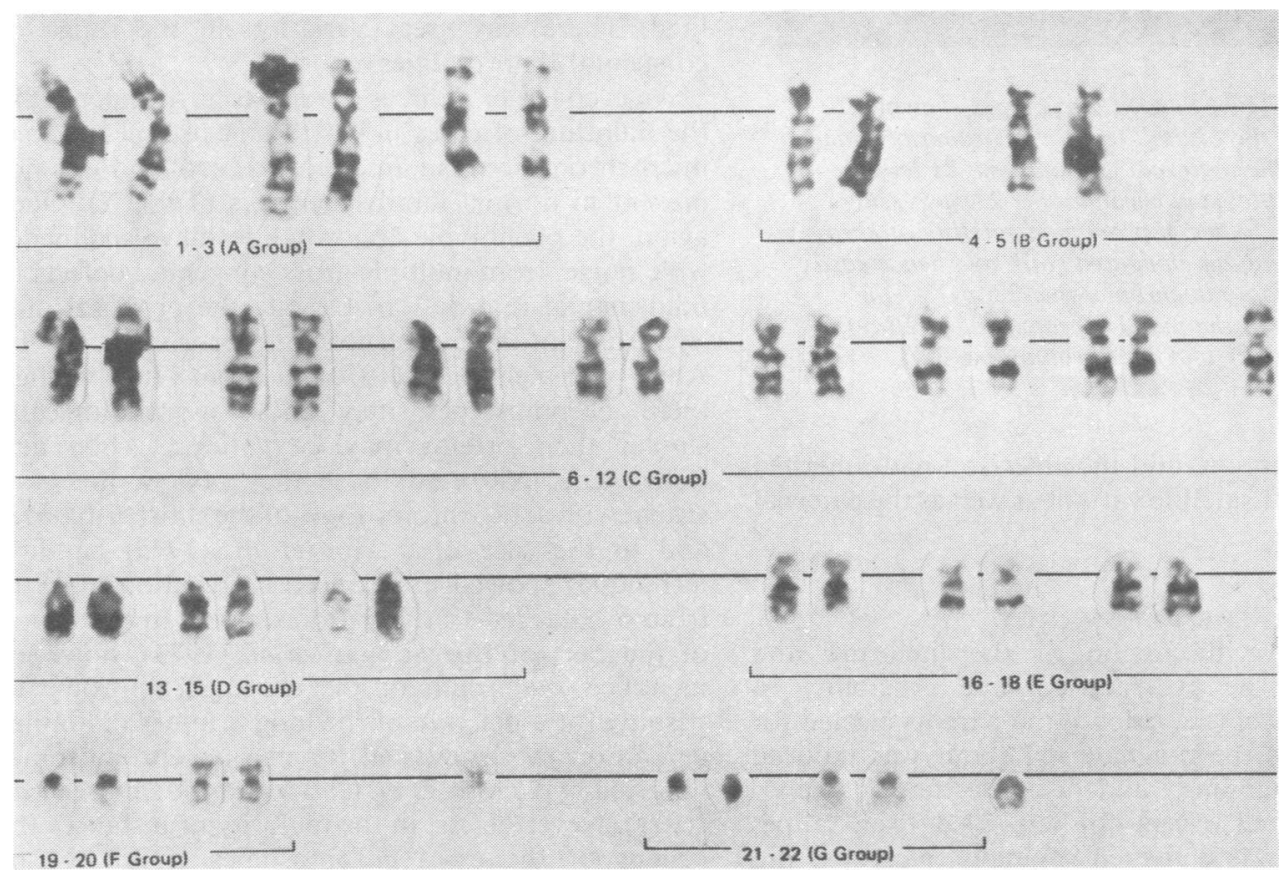

Fig. 2 GTG-banded karyotype of amniotic cells showing non-distinctive banding of the extra metacentric microchromosome. 


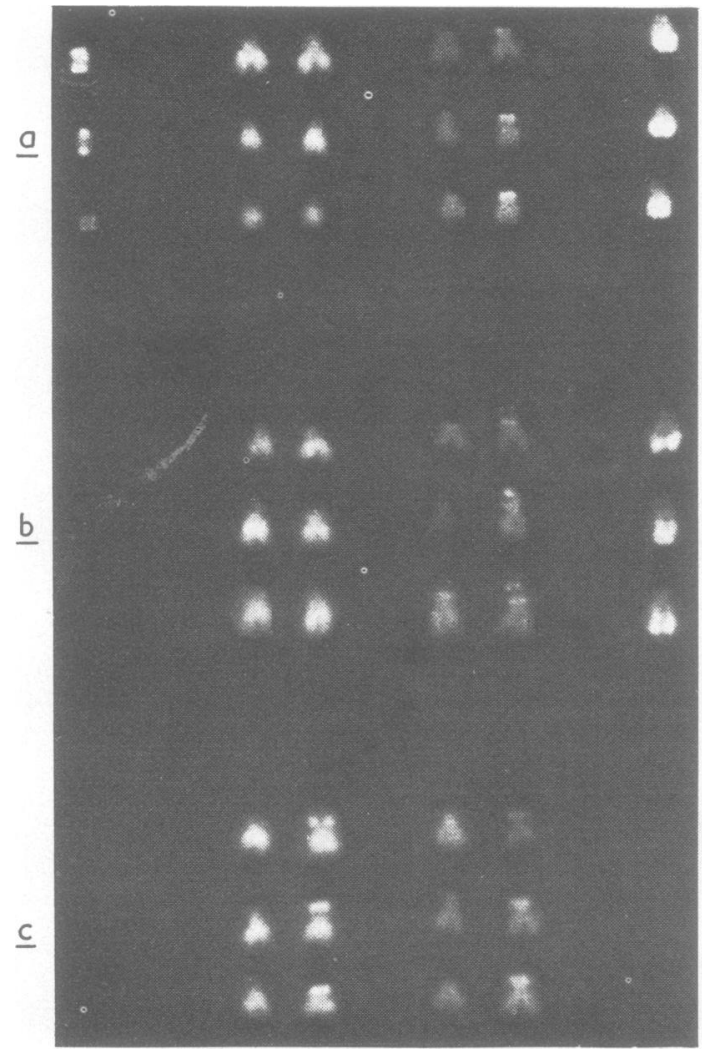

Fig. 3 Partial $Q$-M-banded karyotypes showing (a) in the fetus, the bisatellited microchromosome and segregation of the maternal chromosome 21 lacking prominent satellites and chromosome 22 possessing them; (b) in the father, a prominent satellite of chromosome 22 having an elongated stalk and hence easily differentiable from the chromosome $22, \mathrm{ps}^{+}$of the mother; and $(c)$ in the mother, prominent satellites of one chromosome 21 and one chromosome 22.

by the younger son, and the elder son had inherited the maternal 21 satellite variant as well as the paternal one.

\section{OUTCOME OF THE PREGNANCY}

After extensive discussion of the literature and weighing up the evidence for the possibility of congenital defect (see below), the parents elected for termination of the pregnancy. Labour was induced with prostaglandins, and a male fetus, phenotypically normal except for left-sided fixed talipes equinovarus, was delivered vaginally. Necropsy did not disclose any internal abnormalities in the fetus.

\section{Discussion}

An extra metacentric chromosome has been reported in two large surveys of newborn populations. Walzer et al. (1969) found such a marker chromosome in 3 of 2400 consecutive phenotypically normal infants; in 2 the chromosome was bisatellited, and it was segregating in $\mathbf{2}$ of the $\mathbf{3}$ families. In their survey of 5049 consecutive newborns, Friedrich and Nielsen (1974) detected a bisatellited metacentric microchro- of mosome in 1 abnormal and 2 phenotypically normal $\vec{O}$ infants. The marker was found in normal members of the families of the abnormal and one of the normal $\vec{\omega}$ neonates. In a survey of phenotypically normal adult females, Borgaonkar et al. (1971) found one subject with an extra metacentric chromosome.

It appears from these surveys that an extra microchromosome, usually bisatellited, can occur as an incidental variant marker in phenotypically normal $\omega_{\sigma}$ individuals and their families. On the other hand, $\mathrm{O}$ there are numerous accounts of association of this marker with phenotypic abnormalities. These ac- $>$ counts may be regarded as biased, since the proband would have been referred for cytogenetic assessment because of congenital malformation or mental retardation. In at least 14 such documented cases the marker has also been present in one parent and other phenotypically normal family members (Table 1 ); in 3 families the extra chromosome was bisatellited. There was great variation in the range of congenital abnormalities reported.

An even larger number of reports have appeared in $\overrightarrow{\vec{O}}$ the literature of cases in which an extra metacentric microchromosome in an abnormal proband was not present in normal family members (Table 2). Once again, the phenotypic abnormalities have spanned a wide range, from multiple gross congenital defects to mild mental retardation. Despite the proposal of a 'syndrome of the metacentric microchromosome' by Abbo and Zellweger (1970), it seems that though these chromosomes may look morphologically similar their origins may be various. Abbo and Zellweger's case, and those they review, are con- $D$ sistent with an isochromosome of the short arm of 18 , and in the case of Taylor et al. (1975) banding N techniques showed unbalanced segregation of $18 \mathrm{pi}$ from a balanced translocation carrier. Investigation $N$ of the case of Borgaonkar et al. (1973), however, $N_{\omega}$ identified the origin of the extra chromosome as trisomy for a deletion of the long arm of 22. Similar 0 derivations are suggested for marker chromosomes reported by Uchida et al. (1964) and Macintyre et al. $\stackrel{\mathscr{S}}{\rightarrow}$ (1971). Nevertheless, in the majority of instances the 0 origins of the extra chromosomes could not be identified, though in some they could be inferred from the clinical picture. 
Table 1 Cases referred for abnormality-familial marker present

\begin{tabular}{|c|c|c|c|}
\hline Authors & Year & Phenotype of prospositus & $\begin{array}{l}\text { Presumed chromosome } \\
\text { identity }\end{array}$ \\
\hline $\begin{array}{l}\text { Abbo and Zellweger } \\
\text { Armendares et al. } \\
\text { Borgaonkar et al. } \\
\text { Borgaonkar et al. } \\
\text { Borges and Wald } \\
\text { Frezza et al. } \\
\text { Hoehn } \text { et al. } \\
\text { Mukherjee and Burdette } \\
\text { Nielsen and Hreidarsson } \\
\text { Nielsen } \text { et al. } \\
\text { Pfeiffer } \text { et al. } \\
\text { Smith } \text { et al. } \\
\text { Soudek } \\
\text { Ventruto } \text { et al. }\end{array}$ & $\begin{array}{l}1970 \\
1969 \\
1971 \\
1971 \\
1963 \\
1966 \\
1970 \\
1966 \\
1973 \\
1971 \\
1967 \\
1965 \\
1971 \\
1976\end{array}$ & $\begin{array}{l}\text { 'Syndrome of the metacentric microchromosome' } \\
\text { Multiple congenital abnormalities* } \\
\text { Multiple congenital abnormalities* } \\
\text { Multiple congenital abnormalities* } \\
\text { True hermaphrodite } \\
\text { Familial cerebropathy } \\
\text { Multiple congenital abnormalities* } \\
\text { Features of partial Down's syndrome } \\
\text { Multiple congenital abnormalities* } \\
\text { Oligospermia } \\
\text { Multiple congenital abnormalities* } \\
\text { Oligospermia } \\
\text { Multiple congenital abnormalities* } \\
\text { Kallman's syndrome }\end{array}$ & $\begin{array}{l}\text { ? } 18 \text { pi† } \\
\text { Bisatellited } \\
\text { Non-fluorescent } \dagger \\
\text { Non-fluorescent } \dagger \\
\text { Singly satellited } \\
? \\
? \\
? 21 \text { pi } \\
\text { Bisatellited } \\
?+\text { Yq- } \\
\text { Bisatellited } \\
? \\
? \\
?\end{array}$ \\
\hline
\end{tabular}

* No specific features related to any definite syndrome.

† Marker present in mosaic form in parent.

Table 2 Cases referred for abnormality-marker absent in parents

\begin{tabular}{|c|c|c|c|}
\hline Authors & Year & Phenotype of propositus & Presumed chromosome identity \\
\hline Armendares et al. & 1971 & Microcephaly, facial asymmetry & $?$ \\
\hline Beyer et al. & 1968 & Multiple congenital abnormalities* & $?$ \\
\hline Borgaonkar et al. & 1971 & Multiple congenital abnormalities* & Non-fluorescent \\
\hline Buhler et al. & 1972 & 'Cat-eye' syndrome & $?+22 q-$ \\
\hline Christensen and Nielsen & 1971 & Patient in psychiatric institute & $?+\mathrm{Yq}-$ \\
\hline Crawford and Lele & 1965 & Multiple congenital abnormalities* & $?$ \\
\hline Dekaban and Zelson & 1968 & Features of partial Down's syndrome & Submetacentric ? $+21 q-$ \\
\hline Den Dulk et al. & 1966 & Multiple congenital abnormalities* & \\
\hline Dent et al. & 1963 & Features of partial Down's syndrome & $?+21 \mathrm{q}-$ \\
\hline Dollmann and Jaeger & 1968 & Multiple congenital abnormalities* & $?$ \\
\hline Ferrante et al. & 1968 & Multiple congenital abnormalities* & $?$ \\
\hline Finley et al. & 1971 & Microcephaly - skull asymmetry & Non-satellited, early replicating \\
\hline Frøland et al. & 1963 & Features of partial trisomy 18 & $? 18 \mathrm{der}$ \\
\hline Gamstorp et al. & 1966 & Features of partial Down's syndrome & $?+21 q-$ \\
\hline Gerald et al. & 1968 & 'Cat-eye' syndrome & $?+22 \mathrm{q}-$ \\
\hline Ginsberg et al. & 1968 & 'Cat-eye' syndrome & $?+22 q-$ \\
\hline Gustavson et al. & 1964 & Features of partial trisomy 18 & $? 18 \mathrm{der}$ \\
\hline Hultén et al. & 1966 & Oligospermia & ? \\
\hline Ilberry et al. & 1961 & Features of partial Down's syndrome & $?+21 \mathrm{q}-$ \\
\hline Insley et al. & 1968 & Intersex & $?$ \\
\hline Ishmael and Lawrence & 1965 & Features of partial trisomy D & D group der. \\
\hline Ishmael and Lawrence & 1968 & Mental retard-no specific features & ? \\
\hline Jalbert et al. & 1967 & Multiple congenital abnormalities* & $?$ \\
\hline Mukherjee et al. & 1968 & Microcephaly, facial asymmetry & $?$ \\
\hline Mulcahy and Jenkyn & 1972 & Mental retard-no specific features & Non-satellited \\
\hline Noel and Quack & 1970 & Multiple congenital abnormalities* & ? \\
\hline Schachenmann et al. & 1965 & 'Cat-eye' syndrome & $?+22 q-$ \\
\hline Stevenson et al. & 1966 & Features of partial trisomy D & $?+\mathrm{D} \mathrm{pi}$ \\
\hline Subrt and Prohliková & 1970 & Features of partial Down's syndrome & $?+21 q-$ \\
\hline Taft et al. & 1965 & Features of partial trisomy 18 & $? 18 \mathrm{der}$ \\
\hline Tamburro and Johnson & 1966 & Features of partial trsiomy 18 & $? 18 \mathrm{der}$ \\
\hline Tangheroni et al. & 1973 & Multiple congenital abnormalities* & $?$ \\
\hline Ventruto et al. & 1973 & Psoriasis-normal mentally & ; \\
\hline Warren et al. & 1972 & Features of partial trisomy 18 & $?+18 \mathrm{pi}$ \\
\hline Weber et al. & 1970 & 'Cat-eye' syndrome & $?+22 q-$ \\
\hline
\end{tabular}

* No specific features related to any definite syndrome.

There have been reports of 6 patients in whom the clinical features suggested partial trisomy 21 , and 2 in whom partial trisomy 13 was likely (see Tables 1 and 2). In the review by Freedom and Gerald (1973) of case reports of the 'cat-eye' syndrome first defined by Schachenmann et al. (1965), they point out that in 12 of the 13 patients an extra microchromosome, usually acrocentric rather than metacentric, was present. Buhler et al. (1972) suggested that such cases represented partial trisomy 22 with deletion of the long arm.

In some individuals the extra chromosome may be a partially deleted Y (Christensen and Nielsen, 1971; Nielsen et al., 1971). Price et al. (1976) and Borgaonkar et al. (1971) have reported extra metacentric marker chromosomes in 2 of 611 and 1 of 72 inmates 
of maximum security hospitals, respectively. In the latter case, and one of the former, it was suggested that the marker could represent a deleted $\mathrm{Y}$ chromosome.

Identification of the marker as a derivative of one of the acrocentric chromosomes is facilitated by the presence of satellites on one or both arms. Where the marker is bisatellited it could be an isochromosome of the short arm of an acrocentric chromosome, or have been formed by centric fusion of the short arms of two acrocentric chromosomes during acrocentric association at the time of nucleolar organisation. Court Brown et al. (1966) and Lubs and Ruddle (1971) have shown that variation in length of the short arms and satellite regions of the acrocentric chromosomes are simple human polymorphisms without phenotypic effects. Others, however, have suggested that satellite association may predispose to breakage and translocation, possibly increased where the short arm is enlarged (Ohno et al., 1961; Ferguson-Smith and Handmaker, 1963; Kong-oo Goh, 1968; Bauchinger and Schmid, 1970; Hamerton, 1971). A bisatellited chromosome in a phenotypically normal parent may consequently predispose to non-disjunction at meiosis. In fact, two families in which infants with trisomy 21 have had a phenotypically normal parent with an extra metacentric microchromosome have been reported (Ricci et al., 1968; Mulcahy and Jenkyn, 1972). In the latter family the marker chromosome was bisatellited.

Lubs (personal communication to Friedrich and Nielsen, 1974) found a significantly higher incidence of congenital malformations in children with enlarged G-group satellites, and suggested (Lubs and Ruddle, 1971) that changes in the amount or distribution of heterochromatin may affect the expression of genes and particularly nucleolar organization. Freidrich and Nielsen (1974) have postulated that a bisatellited chromosome by association with acrocentric chromosomes may interfere with mitosis at a critical stage of fetal development.

The prominent satellites and short arms of Ggroup chromosomes in both parents of our case are of particular interest. It is conceivable that the increase of satellite material, and the unusual length of the short arm of chromosome 22 in the father, may have predisposed to centric fusion of the satellited regions and so to formation of the marker chromosome in the fetus.

The presence of a marker microchromosome in mosaic form in a phenotypically normal parent has been reported in 3 cases (Abbo and Zellweger, 1970; Borgaonkar et al., 1971). It is possible that the marker may be selectively lost in successive cell divisions, and disappear gradually with increasing age. A prospective study of phenotypically normal newborns with the marker would be of great interest. It is also possible that gonadal mosaicism may be present in a parent and not be detectable on lymphocyte culture, and thus be responsible for fetal abnormalities. One hundred lymphocyte metaphases of either parent of the present case were examined and revealed no indication of mosaicism.

Evaluation of the significance of the detection of this extra chromosome in amniotic cells presented great difficulty. On the one hand were the findings reported in surveys of phenotypically normal individuals, and on the other were the numerous accounts of variously severe congenital anomalies with extra metacentric microchromosomes. We were fortunate inasmuch as the father is a biologist, able to weigh up the conflicting published accounts for himself, once his attention had been drawn to them. Genetic counselling of a parent without such appropriate training would have been very much more burdensome, since the counsellors could never have been completely certain that the alternative possibilities had been grasped fully. As it happened, the decision of the parents was painfully made, but we believe that it was reached in full understanding of what was involved.

Assessment of the normality of the fetus was not easy. A fixed talipes equinovarus was the only morphological deformity detected. This deformity has been found in association with other congenital abnormalities in a long arm deletion of 13 (Allderdice et al., 1969), occasional cases of trisomy 13, and fairly commonly in trisomy 18 (Warkany et al., 1966). This case was patently none of these. Even where a well-known chromosome anomaly is detected in amniotic culture and subsequently confirmed on fetal karyotyping, the abortus may show no phenotypically recognisable stigmata of the corresponding syndrome. In 5 out of 6 cases of antenatal diagnosis of Down's syndrome, Laurence and Gregory (1976) failed to identify the characteristic Down's features in the fetus. Milunsky (1976) states that 'prenatal genetic studies are unique in that the crucial result depends upon a single laboratory test performed without prior examination of the patient'.

It would be helpful to see in the literature further reports of the antenatal detection of extra metacentric marker chromosomes and of the management of such cases.

We wish to thank Dr A. Porter for referring the patient for genetic counselling; and Drs E. Goudie ? and $T$. Kopenhager for performing the ultrasound examination and amniocentesis, respectively. We also thank Professor Trefor Jenkins for reading and commenting on this paper.

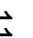

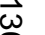
然 


\section{References}

Abbo, G., and Zellweger, H. (1970). The syndrome of the metacentric microchromosome. Helvetica Paediatrica Acta, 25, 83-94.

Allderdice, P. W., Davis, J. G., Miller, O. J., Klinger, H. P., Warburton, D., Miller, D. A., Allen, F. H., Abrams, C. A. L., and McGilvray, E (1969). The $13 \mathrm{q}^{-}$syndrome. American Journal of Human Genetics, 21, 499-512.

Armendares, S., Buentello, L., Cuevas-Sosa, A., and CantúGarza, J. M. (1969). Familial extra centric bisatellited chromosome. Cytogenetics, 8, 177-186.

Armendares, S., Buentello, L., and Salamanca, F. (1971). An extra small metacentric autosome in a mentally retarded boy with multiple malformations. Journal of Medical Genetics, 8, 378-380.

Bauchinger, M., and Schmid, E. (1970). A case with a balanced $\left(14 \mathrm{p}^{+} ; 15 \mathrm{p}^{-}\right)$translocation. Humangenetik, 8, 312-320.

Beyer, P., Ruch, J. U., Rumpler, Y., and Girard, J. (1968). Observation d'un enfant débile mental et polymalformé dont le caryotype montre la presence d'un petit extra chromosome médiocentrique. Pédiatrie, 23, 439-442.

Borgaonkar, D. S., McKusick, U. A., and Farber, P. A. (1973). An inherited small extra chromosome: a mother with $46, X X, t(17 ; 22)(\mathrm{pl} ; \mathrm{ql})$ and a son with $47, \mathrm{XY}+\operatorname{der}(22)$ mat. Journal of Medical Genetics, 10, 379-384.

Borgaonkar, D. S., Schimke, R. N., and Thomas, G. H. (1971). Report of five unrelated patients with a small metacentric extra chromosome or fragment. Journal de Génétique Humaine, 19, 207-222.

Borges, W. H., and Wald, N. (1963). A diminutive satellited chromosome in a father and in one of two true hermaphrodite progeny. Journal of Pediatrics, 63, 474-475.

Buhler, E. M., Méhes, K., Müller, H., and Stalder, G. R. (1972). Cat-eye syndrome, a partial trisomy 22. Humangenetik, 15, 150-162.

Christensen, K. R., and Nielsen, J. (1971). Partial XYY syndrome. Humangenetik, 12, 323-329.

Court Brown, W. M., Buckton, K. E., Jacobs, P. A., Tough, I. M., Kuensberg, E. V., and Knox, J. E. E. (1966). Chromosome studies on adults. Eugenics Laboratory Memoirs. XL.11, Galton Laboratory. Cambridge University Press, London.

Crawford, M. D'A., and Lele, K. P. (1965). A child with an extra small metacentric chromosome. Annals of Human Genetics, 29, 199-205.

Dekaban, A. S., and Zelson, J. (1968). Retardation in a child with an extra submetacentric chromosome fragment and partial mongolism. Journal of Mental Deficiency Research, 12, 216-225.

Den Dulk, G. M., Turner, B., Lee, C., and Quoyle, J. (1966). Chromosomal abnormality: cases with additional chromosome fragments. Medical Journal of Australia, 2, 695-697.

Dent, T., Edwards, J. H., and Delhanty, J. D. A. (1963). A partial mongol. Lancet, 2, 484-487.

Dollmann, A., and Jaeger, W. (1968). Uberzähliges Chromosomenfragment bei einem oligophrenen kind mit multiplen Entwicklungstörungen. Münchner Kinderheil, 116, 144147.

Ferguson-Smith, M. A., and Handmaker, S. D. (1963). The association of satellited chromosomes with specific regions in cultured human somatic cells. Annals of Human Genetics, 27, 143-156.

Ferrante, E., Bruni, L., Laurenti, F., and Cogliati Dezza, G. (1968). Parziale trisomia autosomica in soggetto affeto da ritardo mentale e lievi note dismorfide. Minerva Pediatrica, 20, 522-529.

Finley, W. H., Finley, S. C., and Monsky, D. (1971). An extra small metacentric chromosome in association with multiple congenital abnormalities. Journal of Medical Genetics, 8, 381-383.

Freedom, R. M., and Gerald, P. S. (1973). Congenital cardiac disease in the "cat-eye" syndrome. American Journal of Diseases of Children, 26, 16-18.

Frezza, M., Vettore, L., Perona, G., and De Sandre, G. (1966). Cerebropatia familiare con presenza di un piccolo extracromosoma metacentrico. Folia Hereditaria et Pathologica, 15, 107-114.

Friedrich, U., and Nielsen, J. (1974). Bisatellited extra small metacentric chromosome in newborns. Clinical Genetics, 6, 23-31.

Frøland, A., Holst, G., and Terslev, E. (1963). Multiple anomalies associated with an extra small autosome. Cytogenetics, 2, 99-106.

Gamstorp, I., Häkansson, L., and Lagergren, J. (1966). A case of mental retardation with an additional metacentric chromosome. Hereditas, 55, 266-272.

Gerald, P. S., Davis, D., Say, B. M., and Wilkins, J. L. (1968). A novel chromosomal basis for imperforate anus (the "cat-eye" syndrome). Pediatric Research, 2, 297.

Ginsberg, J., Dignau, P., and Soukeep, S. (1968). Ocular abnormality associated with an extra small autosome. American Journal of Ophthalmology, 65, 740-746.

Gustavson, K. H., Atkins, L., and Patricks, I. (1964). Diverse chromosomal anomalies in two siblings. Acta Paediatrica, 53,371-387.

Hamerton, J. L. (1971). Human Cytogenetics, Vol. 1, pp. 82-100. Academic Press, New York and London.

Hoehn, H., Reinwein, H., and Engel, W. (1970). Genetic studies on a minute centric fragment transmitted through three generations. Cytogenetics, 9, 186-198.

Hultén, M., Lindsten, J., Fraccaro, M., Mannini, A., and Tiepolo, L. (1966). Extra minute chromosome in somatic and germ cell lines of the same person. Lancet, 2, 22-24.

Ilberry, P. L. T., Lee, C. W. G., and Winn, S. M. (1961). Incomplete trisomy in a mongoloid child exhibiting minimal stigmata. Medical Journal of Australia, 48, 182-184.

Insley, J., Rushton, D. I., and Jones, H. W. E. (1968). An intersexual infant with an extra chromosome. Annales de Génétique, 11, 88-94.

Ishmael, J., and Lawrence, K. M. (1965). A probable case of incomplete trisomy of a chromosome of the 13-15 group. Journal of Medical Genetics, 2, 136-141.

Ishmael, J., and Lawrence, K. M. (1968). An extra small metacentric chromosome in a mentally retarded boy. Journal of Medical Genetics, 5, 335-340.

Jalbert, P., Lagier, A., Cachon, J., and Bost, M. (1967). Malformations multiples chez un enfant presentent un chromosome surnuméraire médian et de petite taille. Pédiatrie, 22,963-966.

Kong-oo Goh (1968). Smaller $\mathrm{Gr}\left(\mathrm{Gp}^{-}\right)$and $\mathrm{t}\left(\mathrm{Gp}^{-} ; \mathrm{Dp}^{+}\right)$ American Journal of Diseases of Children, 115, 732-738.

Laurence, K. M., and Gregory, P. (1976). Prenatal diagnosis of chromosome disorders. British Medical Bulletin, 32 , 9-15.

Lubs, H. A., and Ruddle, F. H. (1971). Chromosome polymorphism in American negro and white populations. Nature, 233, 134-136.

Macintyre, M. N., Walden, D. B., and Hempel, J. M. (1971). Tertiary trisomy in a human kindred containing an $E / G$ translocation. American Journal of Human Genetics, 23, 431-441.

Milunsky, A. (1976). Prenatal diagnosis of genetic disorders. New England Journal of Medicine, 925, 377-380.

Mukherjee, D., and Burdette, W. J. (1966). A familial minute isochromosome. American Journal of Human Genetics, 18, 62-69.

Mukherjee, A. B., Partington, M. W., Simpson, N. E., and Walmsley, K. A. (1968). Multiple anomalies associated with 
a small extra metacentric autosome. Journal of Medical Genetics, 5, 329-334.

Mulcahy, M. T., and Jenkyn, J. (1972). Results on 538 chromosome studies on patients referred for cytogenetic analysis. Medical Journal of Australia, 2, 1333-1338.

Nielsen, J., Friedrich, U., and Tsubor, T. (1971). Father and son with karyotype $47, \mathrm{XY}, ?^{7} \mathrm{q}^{-}$. Human Genetics, 11, 247-252.

Nielsen, J., and Hreidarsson, A. B. (1973). Father and daughter with presumptive isochromosome satellitesshort arms D or G. Human Genetics, 19, 271-274.

Noel, B. and Quack, B. (1970). Petit métacentrique surnuméraire chez un polymalformé. Journal de Génétique Humaine, 18, 45-56.

Ohno, S., Trujillo, J. M., Kaplan, W. D., and Kinosita, R. (1961). Nucleolus-organisers in the causation of chromosomal anomalies in man. Lancet, 2, 123-125.

Pfeiffer, R. A., Diekmann, L., and Buchner, T. (1967). Familial occurrence of a small metacentric extra chromosome with satellites on both ends. Annales de Génétique, 10, 124-130.

Price, W. H., Brunton, M., Buckton, K., and Jacobs, P. A. (1976). Chromosome survey of new patients admitted to the four maximum security hospitals in the United Kingdom. Clinical Genetics, 9, 389-398.

Ricci, N., Oentimiglia, B., and Preto, G. (1968). Transmission d'un petit chromosome surnuméraire dans une famille avec deux cas de trisomie 21. Annales Génétique, 11, 114-116.

Schachenmann, G., Schmid, W., Fraccaro, M., Mannini, A., Tiepolo, L., Perona, G. P., and Sartori, E. (1965). Chromosomes in coloboma and anal atresia. Lancet, 2, 290.

Smith, K. D., Steinberger, E., Steinberger, A., and Perloff, W. H. (1965). A familial centric chromosome fragment. Cytogenetics, 4, 219-226.

Soudek, D. (1971). Chromosomal homozygous variants in man. Journal of Human Evolution, 1, 87-88.

Stevenson, R. E., Patterson, R. B., and Goodman, H. O. (1966). Possible autosomal isochromosome in a malformed child. American Journal of Diseases of Children, 111, 327-332.

Subrt, I., and Prohliková, H. (1970). An extra chromosomal centric fragment in an infant with stigmata of Down's syndrome. Journal of Medical Genetics, 7, 407-409.

Taft, P. D., Dodge, P. R., and Atkins, L. (1965). Mental retardation and multiple congenital anomalies. American Journal of Diseases of Children, 109, 554-557.

Tamburro, R. F., and Johnson, C. E. (1966). An extra small metacentric chromosome in a female child. Journal of Medical Genetics, 3, 295-297.

Tangheroni, W., Cao, A., and Furbetta, M. (1973). Multiple anomalies associated with an extra small metacentric chromosome: modified Giemsa stain results. Humangene$t i k, 18,291-295$.
Taylor, K. M., Wolfinger, H. L., Brown, M. G., and Chado wick, D. L. (1975). Origin of a small metacentric chro@ mosome: familial and cytogenetic evidence. Clinica Genetics, 8, 364-369.

Uchida, I. A., Wang, H. C., Laxdal, O. E., Zaleski, W. A and Duncan, B. P. (1964). Partial trisomy-deficiench syndrome resulting from a reciprocal translocation in large kindred. Cytogenetics, 3, 81 -96.

Ventruto, V., Cali, A., Farina, L., Festa, B., Ricciardi, I., an Sebastio, L. (1976). A case of hypogonadotrophic hypogonadism with anosmia (Kallman's syndrome) in a male with familial incidence of a small metacentric chromosom (47,XY,mat, ?+). Journal of Medical Genetics, 13, 71-75. क

Ventruto, V., Rossi, A., and Sebastio, L. (1973). Framment $\vec{\theta}$ cromosomico metacentrico sopranumerario in psoriasici. fenotipicamente normale $(47, \mathrm{XY}, ?+)$. Minerva Medica, 64 1624-1632.

Walzer, S., Breau, G., and Gerald, P. S. (1969). A chromosome survey of 2400 newborn infants. Jdurnal of Pediatrics, 7 438-448.

Warkany, J., Passarge, E., and Smith, L. B. (1966). Congenit malformations in autosomal trisomy syndromes. American Journal of Diseases of Children, 112, 502-517.

Warren, R., Cantwell, R., Kaufman, R., and Condron, (1972). The extra metacentric chromosome-is the supe? numerary chromosome 18 pi? American Society of Human. Genetics, Philadelphia, October (Abstract 12a).

Weber, F. M., Dooley, R. R., and Sparkes, R. S. (1970 Anal atresia, eye anomalies and an additional sma\#abnormal acrocentric chromosome $(47, \mathrm{XX}$, mar. +$)$; report of a case. Journal of Pediatrics, 76, 594-597.

\section{Addendum}

When this case was investigated we had not yeg established recently developed silver staining techniques for the differential staining of satellite regions of acrocentric chromosomes. Such tech= niques should prove informative in the invest接 gation of future similar cases.

Requests for reprints to Dr Renée Bernstein, Depar黑 ment of Human Genetics, School of Pathology, The South African Institute for Medical Research ang University of the Witwatersrand, Hospital Streef P.O. 1038, Johannesburg 2000, South Africa. 